\title{
The liverwort flora of Karelian part of the Vodlozersky National Park (Russia)
}

\author{
Eugene A. Borovichev ${ }^{1} \&$ Ekaterina V. Shorohova ${ }^{2}$ \\ ${ }^{1}$ Institute of the Industrial Ecology Problems of the North of the Kola Science Center of RAS, 184209 Apatity, Russia \\ E-mail: borovichyok@mail.ru \\ ${ }^{2}$ Forest Research Institute of the Karelian Research Centre, Russian Academy of Science, 185910 Petrozavodsk, Russia \\ E-mail: shorohova@es13334.spb.edu
}

\begin{abstract}
An updated list of liverworts in the Karelian part of Vodlozersky National Park is presented, containing 52 species. Twenty-three species were recorded in the National Park for the first time. Heterogemma capitata was found in Karelia for the first time; Calypogeia fissa and Tritomaria exsecta were reported for the second time in the region. The observations of the three species form the northern limit of their global range. New localities are reported for five Karelian red-listed species (Calypogeia suecica, Geocalyx graveolens, Pellia endiviifolia, Scapania apiculata, Syzygiella autumnalis).
\end{abstract}

Keywords: liverworts, Vodlozersky National Park, Republic of Karelia, biodiversity, rare species

\section{INTRODUCTION}

Vodlozersky National Park is located between $62^{\circ} 10^{\prime} \mathrm{N}$ and $63^{\circ} 30^{\prime} \mathrm{N}$ in the eastern part of the Republic of Karelia (Pudozh District) and in the bordering western part of Archangelsk Region (Onega District) (Fig. 1). The protected area covers 468,300 ha, of which 130,600 ha is located in Republic of Karelia and 337,600 ha in Arkhangelsk Region. The National Park was established in 1991 for the study and conservation of the natural and historical sites in the catchment areas of Vodlozero Lake and Ileksa River, for research, education, and recreation purposes, as well as for the restoration of the cultural and historical heritage of the Vodlozero region.

The protected area is located on the southeastern edge of the Fennoscandian (Baltic) Shield, composed of ancient (Archean and Proterozoic) bedrock (Kulikova et al., 1995). The crystalline basement is covered by Quaternary sediments with local bedrock outcrops, e.g. in the upper course of the Ileksa River and in the valleys of Sukhaya Vodla and Vama Rivers (Il'in et al., 1992). The relief, except for the Vetreny Poyas Ridge, was formed by glaciation. Two thirds of the territory is covered by a ground moraine and paludified. One third of the National Park's area is occupied by various glacial formations, rocky outcrops (Vetreny Poyas Ridge), and lake terraces.
The climate is temperate continental with an oceanic influence. Mean annual temperature is $+1.5^{\circ} \mathrm{C}$; mean January temperature is $-11.5^{\circ} \mathrm{C}$, mean July temperature is $+16{ }^{\circ} \mathrm{C}$. The highest recorded temperature is $+32{ }^{\circ} \mathrm{C}$, and the lowest is $-50{ }^{\circ} \mathrm{C}$. Mean annual precipitation is relatively low at $650-700 \mathrm{~mm}$ and is concentrated in the summer months. The growing period lasts 140-150 days (Romanov, 1961). Podzolic and pseudo-podzolic soils, as well as gleyish brown soils dominate in the Karelian part of the $\mathrm{Na}$ tional Park (Berezovsky \& Solomatova, 1995).

Almost one half (45.3\%) of the area is covered by forests. The northern part of the National Park's territory belongs to the northern boreal zone (Aleksandrova \& Yurkovskaya, 1989) and is dominated by open Empetrum-Myrtillus and lichen- and feather moss Norway spruce (Picea abies) forests. The central and southern parts belong to the middle boreal zone of VodlozeroOnegoretcky District, and are dominated by Myrtillus-, Polytrichum-, and Sphagnum spruce forests with an admixture of Scots pine (Pinus sylvestris), birch (Betula pendula, B. pubescens), and aspen (Populus tremula). Birch forests occupy a relatively small fraction of the area (ca. $2 \%$ ). Peatlands cover over 40\% (191,000 ha) (Antipin et al., 2017).

The first list of bryophytes of the National Park (Karelian part only) was published in 2002 (Boi- 
chuk et al., 2002) and included 24 liverworts and 161 mosses. Four species (Liochlaena lanceolata, Lophocolea heterophylla, Lophozia guttulata, and Plagiochila porelloides) were listed as newly observed in the National Park in a study of epiphytic lichens and bryophytes on aspen (Populus tremula) in Karelia (Tarasova et al., 2017). Two red-listed liverwort species (Syzygiella autumnalis and Scapania apiculata) from the National Park were found later (Borovichev et al., 2017). This paper presents a review of all available data on liverworts in the Karelian part of Vodlozersky National Park.

\section{MATERIALS AND METHODS}

The species list was based on published sources and on our own research in the Vodlozersky National Park (Table 1, Fig. 1). About 350 specimens were collected in 2016-2017 by the authors at the source of Sukhaya Vodla River and in the Kuganavolok area (sites 3 and 4 in Table 1, Fig. 2). The species nomenclature generally follows Söderström et al. (2016), common synonyms are given in parenthesis. Species frequency is classified as follows: frequent (species found on more than 10 sites or habitats), sporadic (6-9 sites), rare ( $2-5$ sites), and unique (found only once). Site numbers (in bold, 1-7) are assigned as follows: 1-2 from Boichuk et al., 2002; 3-4 - the authors' own data; 5-7 from Tarasova et al., 2017 (for details see Table 1, Fig. 2). Specimens of complex taxa (e.g. Lophozia s. 1.) referred to in Boichuk et al. (2002) and deposited in KPABG were revised by E.A. Borovichev.

Species in the Red Data Book of Karelia (2007) are denoted as RDBK and the rarity categories are indicated. When a taxon is referred to in

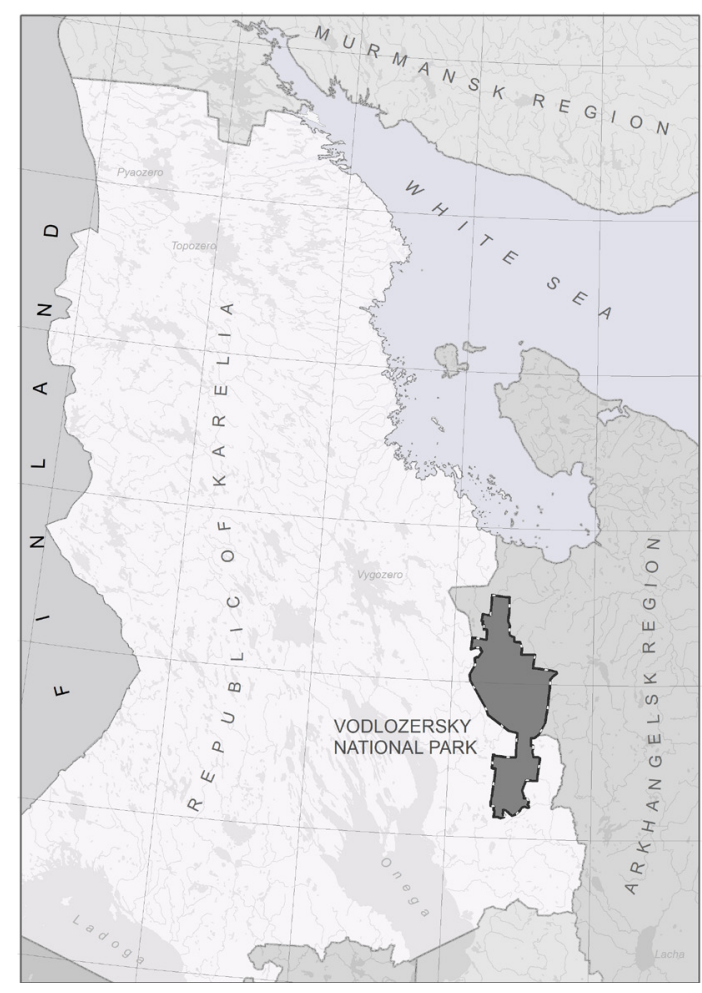

Fig. 1. The location of the Vodlozersky National Park, Arkhangelsk Region and Republic of Karelia, Russia.

a publication, a reference is given. For more common species, habitat characteristics and frequencies are given with the link (in parentheses) to at least one representative specimen in the herbaria; for rare species collected 1-3 times, herbaria references are given for all examined specimens, including collection details. Species newly found in Vodlozersky National Park are

Table 1. Study sites in the Karelian part of Vodlozersky National Park

\begin{tabular}{|c|c|c|c|}
\hline Site & Description & Coordinates & Source \\
\hline 1 & Okhtoma camp site area & $62.268018^{\circ} \mathrm{N} 36.748319^{\circ} \mathrm{E}$ & Boichuk et al., 2002; KPABG \\
\hline 2 & Southern shore of Pil`masozero Lake & $62.451^{\circ} \mathrm{N} 36.686^{\circ} \mathrm{E}$ & Boichuk et al., 2002; KPABG \\
\hline 3 & Kuganavolok Settlement and surroundings & $62.23701^{\circ} \mathrm{N} 36.88488^{\circ} \mathrm{E}$ & collections of the authors 2016-2017 \\
\hline 4 & Sukhaya Vodla River mouth & $62.4824^{\circ} \mathrm{N} 36.9242^{\circ} \mathrm{E}$ & collections of the authors 2016-2017 \\
\hline 5 & Surroundings of Bostilovo village & $62.224180^{\circ} \mathrm{N} 36.753615^{\circ} \mathrm{E}$ & $\begin{array}{l}\text { Tarasova et al., 2017, liverworts identified } \\
\text { by E. Borovichev }\end{array}$ \\
\hline 6 & $\begin{array}{l}\text { Area between Kuganavolok Settlement and } \\
\text { the road to Pudozh }\end{array}$ & $62.201459^{\circ} \mathrm{N} 36.837815^{\circ} \mathrm{E}$ & $\begin{array}{l}\text { Tarasova et al., 2017, liverworts identified } \\
\text { by E. Borovichev }\end{array}$ \\
\hline 7 & Surroundings of Vama village & $62.225730^{\circ} \mathrm{N} 37.084681^{\circ} \mathrm{E}$ & $\begin{array}{l}\text { Tarasova et al., 2017, liverworts identified } \\
\text { by E. Borovichev }\end{array}$ \\
\hline
\end{tabular}




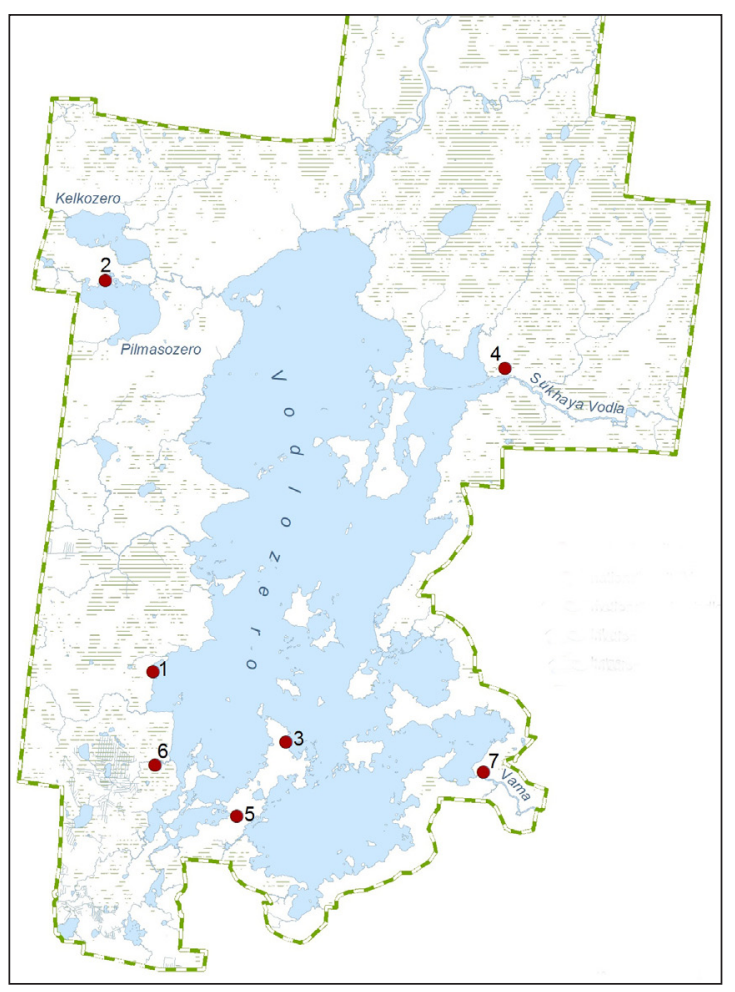

Fig. 2. Study sites in the Karelian part of Vodlozersky National Park.

marked with an asterisk (*), and those newly found in Karelia - with two asterisks $\left(^{* *}\right)$.

The specimens are deposited to the herbaria at the Institute of the Industrial Ecology Problems of the North of the Kola Science Center of RAS (INEP) and at the Polar-Alpine Botanical GardenInstitute of Kola Science Center of RAS (KPABG). Information about the specimens is available from CRIS (Cryptogamic Russian Information System, http://kpabg.ru/cris/?q=node/16).

\section{RESULTS AND DISCUSSION}

The updated list of liverworts in the Karelian part of Vodlozersky National Park includes 52 species. Below, the species are listed in alphabetical order, including species frequency in the National Park, site number (see Table 1 and Fig. 2), vegetation and habitat type where the species was found, and herbarium where the specimen is deposited, or literature references to documented observations (see Material and Methods).

BARBILOPHOZIA BARBATA (Schmidel ex Schreb.) Loeske [=Jungermannia barbata Schmidel ex Schreb., Lophozia barbata (Schmidel ex Schreb.) Dumort.] - Frequent. 1: spruce forest, on the soil (Boichuk et al., 2002); 3: spruce forest, on the ground, collected more than 10 times (INEP 205).

*BARbilophozia hatcheri (A. Evans) Loeske [=Barbilophozia lycopodioides var. hatcheri (A.Evans) Schljakov, Lophozia hatcheri (A.Evans) Steph.] - Rare. 3: mixed spruce and birch forest, on fallen larch and spruce trunks, rarely on spruce stumps and at the base of a trunk, collected more than 5 times (INEP 150).

BARBILOPHOZIA LYCOPODIOIDES (Wallr.) Loeske [=Lophozia lycopodioides (Wallr.) Cogn.] Unique. 2: pebble beach, on a stone (Boichuk et al., 2002).

*Blasia Pusilla L. - Rare. 3: old-growth spruce forest, on clayish soil along an unnamed stream, 8.IX.2017, no Vod18/7-2017 (INEP 165); 4: roadside, on wet soil (INEP 211).

BlepHAROSTOMA TRICHOPHYLLUM (L.) Dumort. - Frequent. 2: three findings on stones (Boichuk et al., 2002, KPABG 109196); 3: old-growth spruce forest, on fallen pine and spruce trunks, collected more than 10 times (INEP 133); 6: mixed aspen-spruce forest at an aspen trunk base (Tarasova et al., 2017).

*CAlypogeia fissa (L.) Raddi - Unique. 3: oldgrowth spruce forest, on clayish soil along an unnamed stream, 8.IX.2017, Vodl8-2017 (INEP 146).

Calypogeia integristipula Steph. - Unique. 2: spruce forest, on the soil (Boichuk et al., 2002).

${ }^{*}$ Calypogeia muelleriana (Schiffn.) Müll.Frib. Rare. 3: old-growth spruce forest, on peat soil in a pit, 8.IX.2017, Vod21-2017 (INEP 145); old-growth spruce forest, on a fallen larch trunk, 8.IX.2017, Л23-2017 (INEP 157).

${ }^{*}$ Calypogeia suecica (Arnell et J. Perss.) Müll. Frib. - Unique. 3: old-growth spruce forest, on a fallen trunk, 8.IX.2017, Л14-2017 (INEP 130). RDBK: 3 (NT).

Cephalozia bicuspidata (L.) Dumort. - Sporadic. 2: pebble beach, on a stone (Boichuk et al., 2002); 3: old-growth spruce forest, on fallen 
larch and spruce trunks, collected more than 10 times (INEP 133).

${ }^{*}$ CePhaloziElla RUbella (Nees) Warnst. [=Cephalozia bifida (Schreb.) Lindb., Cephaloziella bifida (Schreb.) Schiffn.] - Rare. 3: in the vicinity of the National Park Station, mixed spruce and birch forest, on a spruce stump, 9.IX.2017, Vod11/3-4-2017 (INEP177); oldgrowth spruce forest, on a fallen larch trunk, 8.IX.2017, Л7-2017 (INEP175).

Chiloscyphus polyanthos (L.) Corda - Unique. 2: lake shore, on bare loamy soil (Boichuk et al., 2002).

*Conocephalum salebrosum Szweyk., Buczk. et Odrzyk. - Unique. 3: old-growth spruce forest, on clayish soil along an unnamed stream, 8.IX.2017, Vod18/7-2017 (INEP 180).

*CRossocalyx hellerianus (Nees ex Lindenb.) Meyl. [=Anastrophyllum hellerianum (Nees ex Lindenb.) R. M. Schust., Sphenolobus hellerianus (Nees ex Lindenb.) Steph.] - Rare. 3: old-growth spruce forest, on fallen spruce and pine trunks, collected more than 5 times (INEP 190).

*FuscocephalOZiopsis lunUlifolia (Dumort.) Váňa et L. Söderstr. [=Cephalozia lunulifolia (Dumort.) Dumort., Cephalozia media Lindb., Cephalozia media (Spruce) C. Massal.] Sporadic. 3: old-growth spruce forest, on fallen pine, larch, birch, and spruce trunks, collected more than 30 times (INEP 145).

*Fuscocephaloziopsis Pleniceps (Austin) Váňa et L. Söderstr. [=Cephalozia pleniceps (Austin) Lindb.] - Unique. 3: old-growth spruce forest, on a fallen spruce trunk, 8.IX.2017, Vod110/1-2017 (INEP 194).

*GeocalyX GRaveolens (Schrad.) Nees - Unique. 3: old-growth spruce forest, on clayish soil along an unnamed stream, 8.IX.2017, Vod18/4-2017 (INEP 164). RDBK: 4 (DD).

Gymnocolea inflata (Huds.) Dumort. - Unique. 2: swampy spruce forest, waterlogged site (Boichuk et al., 2002, KPABG 108838).

HARPANTHUS FLOTOVIANUS (Nees) Nees - Unique. 2: lake shore, on bare loamy soil (Boichuk et al., 2002, KPABG 102613).

**Heterogemma capitata (Hook.) Konstant. et Vilnet [=Schistochilopsis capitata (Hook.) Konstant., Lophozia capitata (Hook.) Macoun, Massularia capitata (Hook.) Schljakov] - Unique. 4: in the vicinity of Kuganavolok, mixed spruce-birch forest, wet roadside, on the soil, with gemmae, 9.IX.2017, Vod11/92017 (INEP 500834).

*Isopaches BICREnatus (Schmidel ex Hoffm.) H. Buch [=Lophozia bicrenata (Schmidel ex Hoffm.) Dumort.]- Unique. 4: in the vicinity of Kuganavolok, mixed spruce-birch forest, wet roadside, on the soil, 9.IX.2017, Vod11/9-2017 (INEP 192).

LEPIDOZIA REPTANS (L.) Dumort. - Sporadic. 2: three findings on stones and bare soil (Boichuk et al., 2002, KPABG 109196); 3: old-growth spruce forest, mixed spruce and birch forest, on fallen larch and spruce trunks, rarely on spruce stumps, collected more than 5 times (INEP 143).

LIOCHLAENA LANCEOLATA Nees [=Jungermannia subulata var. leiantha (Grolle) Damsh.] Rare. 3: old-growth spruce forest, on a fallen larch trunk, 8.IX.2017, Л4-2017 (INEP 129); 7: old-growth spruce forest, on an aspen trunk (Tarasova et al., 2017).

Lophocolea HETEROPHYlla (Schrad.) Dumort. [=Chiloscyphus profundus (Nees) J. J. Engel et R. M. Schust.] - Frequent. 3: old-growth spruce forest, on fallen spruce, pine, and larch trunks, collected more than 20 times (INEP 130, INEP 145); 4: mixed spruce-birch forest, on fallen spruce and birch trunks and stumps (INEP 164); 6: mixed aspen-spruce forest on an aspen trunk (Tarasova et al., 2017); 7: old-growth spruce forest, on an aspen trunk (Tarasova et al., 2017).

Lophozia gutTulata (Lindb. et Arnell) A. Evans [=Lophozia fauriana Steph., Lophozia longiflora var. guttulata (Lindb. et Arnell) Schljakov, Lophozia ventricosa var. guttulata (Lindb. et Arnell) Bakalin] - Frequent. 2: spruce forest, on a fallen trunk (Boichuk et al., 2002, as Lophozia ventricosa); 3: oldgrowth spruce forest, on fallen larch, spruce, and birch trunks, collected more than 20 times (INEP 134, INEP 129); 4: mixed forest with spruce and birch, on fallen spruce and birch trunks and stumps (INEP 163); 7: old-growth spruce forest, on an aspen trunk base (Tarasova et al., 2017).

*LophOZIA SILVICOla H. Buch - Unique. 2: spruce forest, on stone (Boichuk et al., 2002, as Lophozia ventricosa; KPABG 108789).

LOPHOZIA VENTRICOSA (Dicks.) Dumort. var. LONGIFLORA (Nees) Macoun - Unique. 2: Sphagnum-dominated spruce forest, at base of a spruce tree (Boichuk et al., 2002). 
LOPHOZIOPSIS LONGIDENS (Lindb.) Konstant. et Vi1net [=Lophozia longidens (Lindb.) Macoun] - Frequent. 2: three findings on decaying trunks and tree roots (Boichuk et al., 2002, KPABG 107067, 108691, 108692); 3: oldgrowth spruce forest, on fallen larch, birch, pine, and spruce trunks, rarely on stumps, collected more than 30 times (INEP 128, INEP 142); 6: mixed aspen-spruce forest at an aspen trunk base (Tarasova et al., 2017);

*Marchantia POlymorpha L. subsp. RUDERALIS Bischl. et Boissel.-Dub. [=M. latifolia Gray, Marchantia polymorpha auct. non L.] Unique. 3: Sukhaya Vodla River bank, on the soil, 9.IX.2017, Vodl 6-1-3-2017 (INEP 137);

Neoorthocaulis attenuatus (Mart.) L. Söderstr., De Roo et Hedd. [=Orthocaulis attenuatus (Mart.) A. Evans, Barbilophozia attenuata (Mart.) Loeske, Barbilophozia gracilis Müll. Frib., Lophozia attenuata (Mart.) Dumort., Lophozia gracilis (Schleich. ex Steph.) Steph., Orthocaulis gracilis (Schleich. ex Steph.) H.Buch] - Rare. 2: spruce forest, on the soil (Boichuk et al., 2002, KPABG 108626); 6: mixed aspen-spruce forest on an aspen trunk base (Tarasova et al., 2017).

*NeOorthocaulis floerkei (F.Weber et D.Mohr) L. Söderstr., De Roo et Hedd. [=Orthocaulis floerkei (F. Weber \& D. Mohr) H. Buch, Barbilophozia floerkei (F. Weber et D. Mohr) Loeske, Lophozia floerkei (F. Weber et D. Mohr) Schiffn.] - Unique. 3: in the vicinity of the National Park Station, mixed sprucebirch forest, on a spruce stump, 9.IX.2017, Vod11/1-2017 (INEP 143).

*Obtusifolium obtusum (Lindb.) S. W. Arnell [=Barbilophozia obtusa H.Buch, Lophozia obtusa (Lindb.) A.Evans] - Unique. 3: oldgrowth spruce forest, on clayish soil along an unnamed stream, 8.IX.2017, Vod18/92017 (INEP 198).

Odontoschisma Elongatum (Lindb.) A. Evans Unique. 2: pine forest, on sand, stream bank (Boichuk et al., 2002).

*Pellia endiviffolia (Dicks.) Dumort. - Unique. 3: old-growth spruce forest, on clayish soil along an unnamed stream, 8.IX.2017, Vod18/6-2017 (INEP 199). RDBK: 4 (DD).

Pellia neEsiana (Gottsche) Limpr. - Unique. 2: pebble beach, on stone (Boichuk et al., 2002).

Plagiochila ASPlenioides (L.) Dumort. [=Plagiochila major (Nees) S. W. Arnell, Jungermannia asplenioides L.] - Unique. 2: spruce forest, on the soil (Boichuk et al., 2002, as Plagiochila major; 109173).

Plagiochila PORELloides (Torr. ex Nees) Lindenb. - Rare. 3: in the vicinity of the National Park Station, mixed spruce-birch forest, on the forest litter, 9.IX.2017, Vodl1/8-12-2017 (INEP 155); 7: old-growth spruce forest, at an aspen trunk base (Tarasova et al., 2017).

PTILIDIUM CILIARE (L.) Hampe - Sporadic. 1: spruce forest, on lake shore (Boichuk et al., 2002); 3: in the vicinity of the National Park Station, mixed spruce-birch forest, on boulders, 9.IX.2017, Vodl1/11-2017 (INEP 143).

PTILIDIUM PULCHERRIMUM (Weber) Vain. - Frequent. 2: on decaying wood and bark (pine, spruce, and birch) (Boichuk et al., 2002); 3: oldgrowth spruce forest, on fallen larch, birch, pine, and spruce trunks, on stumps, rarely on wood planks, wooden structures and fragments thereof, collected more than 30 times (INEP 129, INEP 142); 4: mixed spruce and birch forest, on fallen spruce and birch trunks and stumps (INEP 158); 5: middleaged aspen forest, on an aspen trunk (Tarasova et al., 2017); 6: mixed aspen-spruce forest on an aspen trunk (Tarasova et al., 2017); 7: old-growth spruce forest, on an aspen trunk (Tarasova et al., 2017).

Radula Complanata (L.) Dumort. - Sporadic. 2: spruce forest, on aspen bark (Boichuk et al., 2002; KPABG 109381); 3: old-growth spruce forest, on aspen bark, collected more than 5 times (INEP 159); 5: middle-aged aspen forest, on an aspen trunk (Tarasova et al., 2017); 6: mixed aspen-spruce forest on an aspen trunk (Tarasova et al., 2017); 7: oldgrowth spruce forest, on an aspen trunk (Tarasova et al., 2017).

*Riccardia latifrons (Lindb.) Lindb. - Rare. 3: old-growth spruce forest, on a fallen larch trunk, 8.IX.2017, Л12-2017, Л14-2017 (INEP 131).

*Riccardia cf. palmata (Hedw.) Carruth. - Unique. 3: old-growth spruce forest, on a fallen spruce trunk, 9.IX.2017, Vodl 5-1-2017 (INEP 153).

ScAPANiA APICUlata Spruce - Unique. 3: oldgrowth spruce forest, on a fallen spruce trunk, 7.VII.2016, no Л2-2016 (INEP 154; Borovichev et al., 2017). RDBK: 3 (NT).

*Scapania IRRIgua (Nees) Nees - Unique. 3: old-growth spruce forest, in an unnamed 
stream, 8.IX.2017, Vod18/10-2017 (INEP 197).

SCAPANiA MUCRONATA H. Buch - Unique. 2: pine forest, on the sand on a stream bank (Boichuk et al., 2002, KPABG 108626).

*Schistochilopsis Incisa (Schrad.) Konstant. [=Lophozia incisa (Schrad.) Dumort., Massula incisa (Schrad.) Schljakov] - Unique. 3: in the vicinity of the National Park Station, mixed spruce and birch forest, on a spruce stump, 9.IX.2017, Vod11 /6-2017 (INEP 188).

ScHLJAKOVIA KUNZEANA (Huebener) Konstant. et Vilnet [=Orthocaulis kunzeanus (Huebener) H. Buch, Lophozia kunzeana (Huebener) A.Evans] - Unique. 2: Sphagnum-dominated spruce forest, the bottom of a hollow (Boichuk et al., 2002, KPABG 108615).

SchlJAKOVIANTHUS QUADRILOBUS (Lindb.) Konstant. et Vilnet [=Orthocaulis quadrilobus (Lindb.) H. Buch, Barbilophozia quadriloba (Lindb.) Loeske, Lophozia quadriloba (Lindb.) A.Evans] - Unique. 2: pine forest, on the sand on a stream bank (Boichuk et al., 2002, KPABG 108626).

Solenostoma HYALINUm (Lyell) Mitt. [=Plectocolea hyalina (Lyell) Mitt.] - Rare. 2: pebble beach, on a stone (Boichuk et al., 2002, KPABG 108924, 102613).

Solenostoma SPhaerocarpum (Hook.) Steph. Unique. 2: pebble beach, on a stone (Boichuk et al., 2002).

Syzygiella Autumnalis (DC.) K. Feldberg, Vaňa, Hentschel et Heinrichs [=Crossogyna autumnalis (DC.) Schljakov, Jamesoniella autumnalis (DC.) Steph.] - Unique. 3: old-growth spruce forest, on a fallen larch trunk, 7 . VII.2017, Л2-2016 (INEP 163; Borovichev et al., 2017). RDBK: 3 (VU).

*Tritomaria exsecta (Schmidel) Schiffn. ex Loeske - Unique. 3: old-growth spruce forest, on a fallen spruce trunk, 8.IX.2017, Л12-2017 (INEP 131).

The compiled list of liverworts in the Karelian part of Vodlozersky National Park contains 52 species comprising $27 \%$ of the Karelian hepatics flora (186 species) (Borovichev et al., 2017). The species composition of liverworts is rather typical for the middle taiga. A comparison of liverwort species diversity in the National Park and adjacent areas (Kivach State Nature Reserve and Kizhi Reserve), for which more or less complete inventories are available (Table 2), demonstrates high similarities in the liverwort species composition and the dependence of the bryophyte species diversity on the local natural conditions. On the islands of Kizhi Reserve, anthropogenically transformed landscapes and blueberry-and-grass spruce forests dominate (Bakalin, 1999), and the species diversity of liverworts appears to be slightly lower. A slightly higher number of species was found in Kivach State Nature Reserve, where more than $80 \%$ of the area is covered by primeval or semi-natural old-growth middle and south taiga with occasional carbonate rock outcrops (Maksimova et al., 2005).

23 hepatics (Barbilophozia hatcheri, Blasia pusilla, Calypogeia fissa, C. muelleriana, C. suecica, Cephaloziella rubella, Conocephalum salebrosum, Crossocalyx hellerianus, Fuscocephaloziopsis lunulifolia, F. pleniceps, Isopaches bicrenatus, Geocalyx graveolens, Heterogemma capitata, Lophozia silvicola, Marchantia polymorpha, Neoorthocaulis floerkei, Obtusifolium obtusum, Pellia endiviifolia, Riccardia palmata, $R$. latifrons, Scapania irrigua, Schistochilopsis incisa, Tritomaria exsecta) were reported for the first time in Vodlozersky National Park. The majority of the above liverwort species are fairly common in Karelia. The high number of new species was due to the fact that this study covered areas of the National Park with no preexisting inventories.

In addition, new occurrences of some very rare species were discovered, expanding the existing knowledge of their distribution patterns in Karelia and the North-West of Russia. Of these, Heterogemma capitata has never been observed in the region. This northern suboceanic species is rare in Russia and was only known from Khanty-Mansy Autonomous District (Konstantinova, Mamontov, 2009), Republic of Buryatiya (Afonina et al., 2018), Nizhny Novgorod Region (Konstantinova, 2004; Andrejeva, Schestakova, 2009), Kaliningrad Region (Dietzow, 1938), and St. Petersburg (Sofronova et al., 2015). In the Nordic countries, Heterogemma capitata occurs sporadically in the southern regions of Denmark, Sweden, Finland and is very rare in Norway (Damsholt, 2002). The closest to Karelia observations of the species come from southern Finland (Laaka-Lindberg et al., 2009) and Kolpino District, Leningrad Region (Potemkin et al., 
Table 2. Number of liverwort species in the three protected areas in Karelia

\begin{tabular}{llll}
\hline Protected area & Area, ha & $\begin{array}{l}\text { Number of } \\
\text { liverwort } \\
\text { species }\end{array}$ & \\
\hline $\begin{array}{l}\text { Vodlozersky National Park (Karelian } \\
\text { part) }\end{array}$ & 130,600 & 52 & $\begin{array}{l}\text { Boichuk et al., 2002; Tarasova et al., 2017; our } \\
\text { data }\end{array}$ \\
Kivach State Nature Reserve & 10,880 & 56 & $\begin{array}{l}\text { Maksimova et al., 2005; Borovichev et al., } 2017 \\
\text { Kizhi State Reserve }\end{array}$ \\
& $\begin{array}{l}50,000 \text { (incl. } \\
27,000 \text { ha of } \\
\text { waterbodies) }\end{array}$ & 45 & Bakalin, 1999; Tarasova et al., 2017 \\
\hline
\end{tabular}

2015). In Finland, the species is extinct in three of the four known localities (Laaka-Lindberg et al., 2009).

Calypogeia fissa and Tritomaria exsecta were reported in Karelia for the second time. The suboceanic species Calypogeia fissa was earlier known from the biogeographical province Karelia Borealis located in Suojärvi District (Arnell, 1956; Potemkin, 2018). The species is very rare in Russia (Konstantinova et al., 2009; Potemkin, 2018), and the nearest occurrences outside $\mathrm{Ka}$ relia are in southern Finland (Laaka-Lindberg et al., 2009) and in Leningrad Region (Potemkin et al., 2017). Tritomaria exsecta was earlier found in Kivach State Nature Reserve only (Ellis et al., 2016) and the nearest European occurrences of the species are in Komi (Dulin, 2007), Arkhangelsk (Zickendrat, 1900) and Leningrad (Potemkin \& Andrejeva, 1999) Regions. Thus, the observations of the species in Karelia suggest the northernmost limit of its global range. This liverwort species is recommended for inclusion in the upcoming edition of the Red Data Book of Karelia as an Endangered Species.

We found new occurrences of five Karelian redlisted species (Red Data Book, 2007): Calypogeia suecica (Vulnerable), Geocalyx graveolens (Data Deficient), Pellia endiviifolia (Data Deficient), Scapania apiculata (Near Threatened), Syzygiella autumnalis (Vulnerable). Three species (Calypogeia suecica, Scapania apiculata, Syzygiella autumnalis) are indicators of old-growth and virgin boreal forests (Konechnaya et al. 2009). The primary limiting factor for these species is the reduction of the forest area due to logging and deforestation. At the same time, the hepatics Geocalyx graveolens and Pellia endiviifolia are neither threatened nor confined to unique communities in Karelia.
Our findings suggest that the liverwort flora of Vodlozersky National Park is rich. Further studies are needed in the Arkhangelsk part of the National Park and in areas with limestone outcrops, extended mire complexes, and anthropogenic habitats.

\section{ACKNOWLEDGEMENTS}

We thank the administration of Vodlozersky National Park for their comprehensive assistance in the organization of field trips, Dr. V. Mamontov and O. Petrova for the preparation of maps, Dr. N. Koroleva for valuable comments. Special thanks to two reviewers for their constructive suggestions which substantially improved the manuscript. The study was carried out as part of the State Research Program of the Institute of Industrial Ecology of the North, KSC RAS (AAAA-A18-118021490070-5), the State Research Programme of the Forest Research Institute of the Karelian Research Centre, RAS and was partly supported by the Russian Science Foundation (project 15-14-10023), Russian Foundation for Fundamental Research (research project 18-04-00594).

\section{REFERENCES}

Afonina, O. M., Mamontov, Yu. S., Tubanova, D. Ya., Czernyadjeva, I. V., Kazanovsky, S. G. 2018. On the Bryophyte flora of Svyatoy Nos Peninsula of Baikal Lake (Buryatia). Botanical Journal 103(4): 466-487. (In Russian with English abstract).

Aleksandrova, V. D., Yurkovskaya, T. K. 1989. Geobotanical zoning of non-black soil area of the European part of the RSFSR. Leningrad. 64 pp. (In Russian).

Andrejeva, E. N., Schestakova, A. A. 2009. New liverwort records from Nizhni Novgorod Region. Arctoa 18: 255-257. (In Russian).

Antipin, V. K., Boychuk, M. A., Shreders, M. A. 2017. The digital maps of mires vegetation in the 
southern part of the "Vodlozersky" National Park. Transactions of the Kola Science Centre. Applied Ecology of the North 7 (41): 65-79. (In Russian).

Arnell, S. 1956. Hepaticae. Illustrated moss Flora of Fennoscandia 1. Lund. 308 pp.

Bakalin, V. A. 1999. To the liverworts flora of the Kizhskie Shery. Novosti Sist. Nizsh. Rast. 33: 180-184. (In Russian).

Berezovsky, V. A., Solomatova, E. A. 1995. On the soils of the Vodlozersky National Park. In: Natural and cultural heritage of the Vodlozersky National Park: 130-133. Petrozavodsk. (In Russian).

Boichuk, M. A., Antipin, V. K., Bakalin, V. A., Lapshin P. N. 2002. Contribution on the Bryoflora of Vodlozersky National Park. Novosti Sist. Nizsh. Rast. 36: 213-224. (In Russian with English abstract).

Borovichev, E. A., Shorohova, E. V., Ilina O. V., Maksimov, A. I., Potemkin, A. D., Maksimova, T. A. 2017. New data on the distribution of rare and red-listed species of liverworts on the Republic of Karelia. Transactions of KarRC of RAS 1: 110-116. (In Russian with English abstract). https://doi. org/10.17076/bg527

Damsholt, K. 2002. Illustrated flora of Nordic liverworts and hornworts. Nordic Bryological Society, Lund. 840 pp.

Dietzow, L. 1938. Die Moose Altpreu und ihre Standorte. Jahresbericht des Preussischen botanischen Vereins. 84 pp.

Dulin, M. V. 2007. Liverworts of the Middle Taiga Subzone of the Russian European North-East. Ekaterinburg. 195 pp. (In Russian).

Ellis, L. T., Alataş, M., Asthana, A. K., Rawat, K. K., Sahu, V., Srivastava, A., Bakalin, V. A., Batan, N., Bednarek-Ochyra, H., Bester, S. P., Borovichev, E. A., De Beer, D., Enroth, J., Erzberger, P., Fedosov, V. E., Feuillet-Hurtado, C., Gradstein, S. R., Gremmen, N. J. M., Hedenäs, L., Katagiri, T., Yamaguchi, T., Lebouvier, M., Maity, D., Mesterhazy, A., Müller, F., Natcheva R., Nemeth, Cs., Opisso, J., Ozdemir, T., Erata, H., Parnikoza, I., Plášek, V., Sabovljević, M. S., Sabovljević, A. D., Saha, P., Nehal Aziz, Md., Schröder, W., Váňa, J., van Rooy, J., Wang, J., Yoon, Y.-J. \& Kim, J. H. 2016. New national and regional bryophyte records, 47. Journal of Bryology 38 (2): 151-168. https://doi.org/10.1080/03736687.2016.117 1453

Il'in, V. A., Kulikova, V. V., Antipin, V. K. 1992. Geological and geomorphological characteristics of the National Park Vodlozersky. In: Geology and conservation of the bowels of the Republic of $\mathrm{Ka}$ relia: 42-51. Petrozavodsk. (In Russian).

Konechnaya, G. Yu., Kurbatova, L. E., Potemkin, A. D., Himelbrant, D. E., Kuznetsova, E. S., Zmitrovich, I. V., Kotkova, V. M., Malysheva, V. F., Morozova, O. V., Popov, E. S., Yakovlev, E. B., Andersson, L., Kiyashko, P. V., Skujienè, G. 2009. The identification and examination of biologically valuable forests in the North-West of the European part of
Russia. Volume 2. Manual for identification of species used in the survey at the level of allotments. Sankt-Petersburg. 258 pp. (In Russian).

Konstantinova, N. A. Hepatics of the Kerzhenskiy State Reserve (Nizhniy Novgorod Province, European Russia). Arctoa 13: 89-99. (In Russian with English abstract). https://doi.org/10.15298/ arctoa. 13.12

Konstantinova, N. A., Mamontov, Yu. S. 2009. New liverwort records from Omsk Province. 1. Arctoa 18: 267. https://doi.org/10.15298/arctoa.18.02

Konstantinova, N. A., Bakalin, V. A., Andreeva, E. N., Bezgodov, A. G., Borovichev, E. A., Dulin, M. V. \& Mamontov Yu. S. 2009. Checklist of liverworts (Marchantiophyta) of Russia. Arctoa 18: 1-63. https://doi.org/10.15298/arctoa.18.01

Kulikova, V. V., Kulikov, V. S., Bychkova, Ya. V. 1995. Geological structure of the crystalline basement of the National Park Vodolozersky. In: Geology and conservation of the bowels of the Republic of Karelia: 17-33. Petrozavodsk. (In Russian).

Laaka-Lindberg, S., Anttila, S., Syrjänen, K. 2009. Suomen uhanalaiset sammalet. Helsinki. 347 pp.

Maksimova, T. A., Potemkin, A. D., Maksimov, A. I. 2005. To the hepatic flora of the Kivach Reserve. In: Topical Issues of Bryology: Collection of Papers Following the International Meeting Dedicated to the 90th Anniversary of A. L. Abramova. Pp. 120-126. Sankt-Petersburg. (In Russian with English summary).

Potemkin, A. D. \& Andrejeva E. N. 1999. Liverworts and hornworts of the Leningrad region. In: Balashova, N. B. \& Zavarzin, A. A. (eds). Biodiversity of Leningrad Province (Algae. Fungi. Lichens. Bryophytes. Invertebrates. Fishes and pisciformes): 261-270. Sankt-Petersburg. (In Russian).

Potemkin, A. D. 2018. Calypogeia fissa (Calypogeiaceae, Marchantiophyta) in the Northwestern European Russia. Novosti Sist. Nizsh. Rast. 52(1): 173-181. https://doi.org/10.31111/nsnr /2018.52.1.173

Red Data Book of Karelian Republic. 2007. Petrozavodsk. 368 pp. (In Russian).

Romanov, A. A. 1961. To the climate of Karelia. Petrozavodsk. 140 pp. (In Russian).

Söderström, L., Hagborg, A., von Konrat, M., Bartholomew-Began, S., Bell, D., Briscoe, L., Brown, E., Cargill, D. C., Costa, D. P., Crandall-Stotler, B. J., Cooper, E. D., Dauphin, G., Engel, J. J., Feldberg, K., Glenny, D., Gradstein, S. R., He, X., Heinrichs, J., Hentschel, J., Ilkiu-Borges, A. L., Katagiri, T., Konstantinova, N. A., Larraín, J., Long, D. G., Nebel, M., Pócs, T., Puche F., Reiner-Drehwald E., Renner M. A. M., Sass-Gyarmati A., SchäferVerwimp A., Segarra-Moragues, J. G., Stotler, R. E., Sukkharak, P., Thiers, B. M., Uribe, J., Váňa, J., Villarreal, J. C., Wigginton, M., Zhang, L. \& Zhu, R.-L. 2016. World checklist of hornworts and liverworts. PhytoKeys 59: 1-828. https:// doi.org/ 10.3897/phytokeys.59.6261 
Sofronova, E. V. (ed.), Afonina, O. M., Akatova, T. V., Andrejeva, E. N., Baisheva, E. Z., Bezgodov, A. G., Blagovetshenskiy, I. V., Borovichev, E. A., Chemeris, E. V., Chernova, A. M., Czernyadjeva, I. V., Doroshina, G. Ya., Dudareva, N. V., Dudov, S. V., Dulin, M. V., Fedosov, V. E., Gabitova, S. M., Ignatov, M. S., Ignatova, E. A., Kapitonova, O. A., Kazanovsky, S. G., Kotkova, V. M., Lavrinenko, O. V., Mamontov, Yu. S., Mežaka, A., Mochalova, O. A., Nikolajev, I. A., Noskova, E. Yu., Notov, A. A., Philippov, D. A., Pisarenko, O. Yu., Popova, N. N., Potemkin, A. D., Rozantseva, E. I., Teleganova, V. V., Tsegmed, Ts., Zolotov, V. I. 2015. New Bryo- phyte Records. Arctoa 24: 224-264. https://doi. org/10.15298/arctoa.24.23

Tarasova, V. N., Obabko, R. P., Himelbrant, D. E., Boychuk, M. A., Stepanchikova, I. S., Borovichev, E. A. 2017. Diversity and distribution of epiphytic lichens and bryophytes on aspen (Populus tremula) in the middle boreal forests of Republic of Karelia (Russia). Folia Cryptog. Estonica 54: 125-141. https://doi.org/10.12697/fce.2017.54.16

Zickendrath, E. 1900. Beitrage zur Kenntniss der Moosflora Russlands. II. Bull. Soc. Natur. Moscou. 14(3): 241-366. 
86 Folia Cryptog. Estonica 